\title{
PREVALENCE OF RACES AND BIOTYPES OF RALSTONIA SOLANACEARUM IN INDIA
}

\author{
Krishnappa Nagarathna Chandrashekara ${ }^{1 *}$, Mothukapalli Krishnareddy Prasannakumar ${ }^{2}$, \\ Manthirachalam Deepa ${ }^{3}$, Akella Vani ${ }^{1}$, Abdul Nazir Ahmad Khan ${ }^{2}$
}

\author{
${ }^{1}$ Division of Biotechnology, Indian Institute of Horticultural Research \\ Hessaraghatta Lake post, Bangalore - 560 089, India \\ ${ }^{2}$ Department of Plant Pathology, University of Agricultural Science \\ Gandhi Krishi Vigyana Kendra, Bangalore - 560 064, India \\ ${ }^{3}$ Division of Soil Science, Indian Institute of Horticultural Research \\ Hessaraghatta Lake post, Bangalore - 560 089, India
}

Received: January 10, 2011

Accepted: September 22, 2011

\begin{abstract}
Bacterial wilt caused by Ralstonia solanacearum is the most destructive disease of plants. Fifty-seven isolates of $R$. solanacearum causing wilt on different host plants viz., tomato (Solanum lycopersicum), brinjal (S. melongena), potato (S. tuberosum), bird of paradise (Strelitzia reginae), ginger (Zingiber officinale), chili (Capsicum annuum), capsicum (Capsicum annuum), davana (Artemisia pallens) and coleus (Coleus forskohlii) were collected from the different agro climatic zones of Karnataka and other parts of India. In this study, 57 isolates were differentiated into race on the basis of their pathogenicity and their ability to infect different host. The isolates were established as race-1. None of the isolates infected mulberry and banana. Fifty-four isolates oxidized and utilized both the disaccharides and sugar alcohols. These isolates were positioned as biovars-3 according to Haywards classification system. Three isolates from Kerala, two ginger, and one tomato strain were not able to utilize dulcitol and lactose. Hence, they were categorized into a new taxo group within the system and designated as biovar-3B for the first time in India. There were 54 isolates which were confirmed as race-1, biovar-3, and 3 isolates were confirmed as race-1, biovar-3B by morphological, physiological, biochemical and pathogenicity studies. Two sets of primers (OLI1 \& Y2 and Y1 \& Y2) were used in this study to authenticate the organism. Furthermore, the identity of the isolates was confirmed by a serological diagnostic kit obtained from the International Potato Research Center, Lima, Peru, and single chain variable fragment antibody specific to $R$. solanacearum.
\end{abstract}

Key words: Ralstonia solanacearum, race, biovar, Kerala, taxo

\section{INTRODUCTION}

Ralstonia solanacearum (Pseudomonas solanacearum) (E.F. Smith) (Yabuuchi et al. 1995) as a species has an extremely wide host range. Different pathogenic varieties (races) within the species, though, may show more restricted host ranges. Several hundred species of tropical, subtropical and warm temperature plants are susceptible to one or more of the races of $R$. solanacearum. The results are heavy losses in many economically important crops (Hayward 1991; Chandrashekara and Prasannakumar 2010). R. solanacearum is highly heterogeneous and complex. It is a major constraint in the production of many important vegetables, fruit, and cash crops. This devastating, soil-borne plant pathogen has a global distribution and an unusually wide host range. $R$. solanacearum causes wilt in over 450 host species in 54 botanical families (Allen et al. 2005) which may give the pathogen an evolutionary advantage. The number of new species continues to increase (Hayward 1991).
The race and biovar classification has gained wide acceptance for subdividing $R$. solanacearum. The racial pattern system groups the strains of $R$. solanacearum according to their ability to infect different host plants, viz., race 1 is comprised of many strains having a wide host range and pathogenic on different solanaceous plants and weed hosts, race 2 is restricted to triploid banana and Heliconia, race 3 (potato race) affects potato, race 4 infects ginger, and race 5 is pathogenic on mulberry (He et al. 1983). The biovar scheme divides the species into five groups on the ability of the strains to metabolise or oxidise specific hexose sugars and disaccharides (Hayward 1991). At present, there is lot of controversy regarding the prevalence of strains in the various parts of the world. In India however, scant information is available about the prevalence of biovars/races and strains in various parts of the country. Therefore, the present investigations on 57 isolates of $R$. solanacearum causing wilt on different host plants were carried out. The objectives were to find the races and bi- 
ovars prevailing in different agro climatic zones of Karnataka and other parts of India.

\section{MATERIALS AND METHODS}

\section{Isolation of $R$. solanacearum strains from the field}

Wilt affected host plants viz., tomato (Solanum lycopersicum), brinjal (S. melongena), potato (S. tuberosum), bird of paradise (Strelitzia reginae), ginger (Zingiber officinale), chili (Capsicum annuum), capsicum (Capsicum annuum), davana (Artemisia pallens) and coleus (Coleus forskohlii) showing typical symptoms of wilt were collected from different agro climatic zones of Karnataka and other parts of India (Table 1). An appropriate water streaming test was carried out as described by Danks and Barker (2000). Bacterium was isolated on Semi-selective media South Africa (SMSA) media (Elphinstone et al. 1998; Wenneker et al. 1999). The isolates were subjected to identification and confirmation based on morphological, physiological, cultural, biochemical and pathogencity studies (Kelman 1954). The isolates were differentiated into biovars according to the description of Schaad 1988 and Hayward 1991.

\section{Pathogenicity test on different hosts}

Fifty-seven isolates of $R$. solanacearum were multiplied in casein peptone glucose (Casamino acid $1 \mathrm{~g} / \mathrm{l}$, Peptone $10 \mathrm{~g} / \mathrm{l}$, Glucose $10 \mathrm{~g} / \mathrm{l} \mathrm{pH}$ 7.2) to inoculate on differential hosts under artificial conditions. The bacterial suspension was adjusted to a concentration of $5 \times 10^{8} \mathrm{cfu} / \mathrm{ml}$ using spectrophotometer readings (Spectronic $20 \mathrm{D}, \mathrm{M}$ and $\mathrm{R}$, USA) at a wave length equivalent to $\mathrm{A} 600 \mathrm{~nm}=0.8$ to 1.0. Plants used as differential hosts viz., tomato (Lycopersicon esculentum Mill.) cv. Avinash-II, banana (Musa accuminata) cv. yallaki bale, ginger (Z. officinale), mulberry (Morus alba) cv. M-5 and potato (S. tuberosum) cv. kufri jyothi seedlings were grown in greenhouse under artificial conditions. Twenty-day-old seedlings of tomato were pulled out gently, washed free of soil and a few tertiary roots were clipped with sterilized scissors and dipped in the bacterial culture for 10 minutes. The inoculated seedlings were transplanted to plastic bags containing sterilized soil. In situ inoculation of potato, banana, mulberry and ginger plants was carried out by scrapping off the surface soil and pouring $20 \mathrm{ml}$ of bacterial suspension around the roots separately with each isolate, and then all was covered with soil. Plants similarly inoculated with sterile water served as the control.

\section{Sugar utilization test}

The isolates were differentiated into biovars as described by Schaad 1988, using carbohydrate fermentation discs to confirm the obtained results. The bacterial suspension belonging to 57 isolates containing a population of $5 \times 10^{8} \mathrm{cfu} / \mathrm{ml}$, were seeded separately with 0.8 Optical Density (OD) in a spectrophotometer at $600 \mathrm{~nm}$. The flask was mixed to get a uniform suspension. The seeded medium was poured onto a petri plate and was allowed to cool for 3 hrs. Then, fermentation discs viz., cellobiose, lactose, maltose and sugar alcohols such as dulcitol, man- nitol and sorbitol were placed in marked positions in three locations. A total of nine discs were maintained and plates were incubated at $32^{\circ} \mathrm{C}$ for $48 \mathrm{hrs}$. Observations were made and changes in colour recorded. Observations were recorded once at 18-24 hrs and again at the end of 48 hrs. A hypersensitive test on tobacco was carried out to determine plant pathogen presence and its virulence (Granada and Sequeira 1975). All tests viz., starch hydrolysis, nitrate reduction, oxidase, indole production, esculin hydrolysis, arginine dihydrolase, and curdling of skimmed milk were carried out using the methods described in the Manual of Microbial methods (Anonymous 1957) and the Laboratory guide for identification of Plant Pathogenic Bacteria (Schaad 1988).

\section{Genomic DNA extraction and purification}

$R$. solanacearum culture purified on SMSA was used for inoculation and incubated overnight in $100 \mathrm{ml}$ of casein peptone glucose (CPG) medium at room temperature. Bacterial culture was centrifuged, $(7,000 \mathrm{rpm}$ for $10 \mathrm{~min}$ ) and pellets were frozen at $-20^{\circ} \mathrm{C}$ for $2 \mathrm{hrs}$. Frozen bacterial pellets were thawed for $3 \mathrm{~min}$ at $37^{\circ} \mathrm{C}$, suspended in $10 \mathrm{ml}$ of lysis buffer $(0.15 \mathrm{M} \mathrm{NaCl}, 0.05 \mathrm{M}$ sodium citrate buffer) and further incubated with $200 \mu \mathrm{l}$ of lysozyme $(10 \mathrm{mg} / \mathrm{ml})$ at $37^{\circ} \mathrm{C}$ for $60 \mathrm{~min}$. The cells were lysed with $500 \mu \mathrm{l}$ of $20 \%$ Sodium dodecyl sulfate (SDS) by gently shaking. Next, $15 \mathrm{ml}$ of extraction buffer were added [ $2.5 \mathrm{ml}$ of $5 \mathrm{M}$ sodium per chlorate and $12.5 \mathrm{ml}$ of chloroform: isoamylalcohol mixture (24:1)]. The contents were incubated at $-20^{\circ} \mathrm{C}$ for $2 \mathrm{hrs}$ and centrifuged at 5,000 rpm for $10 \mathrm{~min}$. Supernatant was precipitated with an equal volume of isopropanol, washed with $70 \%$ ethanol, the DNA was air dried and dissolved in $1 \mathrm{ml} \mathrm{T}_{10} \mathrm{E}_{1}$ buffer. After quantification on a spectrophotometer, the DNA was analysed on agarose $0.7 \%$ gel electrophoresis.

\section{Polymeraze chain reaction (PCR) amplification and se- rological detection}

All 57 isolates were PCR amplified using two sets of primers corresponding to $16 \mathrm{~S}$ rDNA(OLI1 and Y2) and $16 \mathrm{~S}$ rRNA (Y1 and Y2), as described by Seal et al. 1993, using universal primers (OLI1- 5'GGGGGTAGCTTGCTACCTGCC3' \& Y2-5'CCCACTGCTGCC TCCCGTAGGAGT3') and (Y1-5'TGGCTCAGAACGAACGCGGCGGC3' \& Y25'CCCACTGCTGCCTCCCGTAGGAGT3'). PCR products were resolved on $1.2 \%$ agrose gel.

Serological confirmation was carried out by using CIP's post-enrichment Double Antibody Sandwich ELISA (DAS-ELISA) kit, International Potato Center, Lima, Peru, (Priou et al. 1999). Monoclonal scFv antibody specific to $R$. solanacearum race-1, biovar-3 (Chandrashekara et al. 2006) was used to confirm bacterial isolates. The microtitre plate was coated with $60 \mathrm{mg}$ of $R$. solanacearum antigen per well with $200 \mathrm{ml}$ of carbonate buffer, and $\mathrm{pH}$ 9.6 along with appropriate controls, then incubated overnight at room temperature. The wells were rinsed three times with 1X Phosphate buffered saline (PBS) and excess buffer was removed by flipping over the plate. The plate was blocked with $200 \mathrm{ml}$ of 3\% Bovine serum albumin (BSA) in 1X PBS for 90 minutes at room temperature and then rinsed three times with $1 \mathrm{X}$ PBS. Two hundred $\mathrm{ml}$ of 
anti - R. solanacearum - Alkaline phosphatase (ALP) conjugate in 1:10 dilution was prepared in 3\% BSA-1X PBS and added to each well except for the control well. The microtitre plate was incubated for 90 minutes at room temperature and washed three times with 1X PBS-Tween 20. An addition of $200 \mathrm{ml}$ of pNPP substrate was added to all the wells, and they were incubated in the dark for 30 minutes. A reading was taken at $415 \mathrm{~nm}$.

\section{RESULTS}

\section{Isolation of $R$. solanacearum strains from the field}

Isolation of the bacterium was done from tomato (S. lycopersicum), brinjal (S. melongena), potato (S. tuberosum), bird of paradise (Strelitzia reginae), ginger (Z. officinale), chili (C. annuum), capsicum (C. annuum), davana (A. pallens) and coleus (C. forskohlii) plants showing typical symptoms of bacterial wilt. Such signs were: lower leaves turning pale yellow, loss of leaf turgidity followed by drooping of leaves and sudden wilt of the plants. The vascular bundles of the infected plants showed brown discoloration. Plants with symptoms were collected from different agro climatic regions of Karnataka and various parts of India (Table 1). Tentative diagnosis of the diseased plants collected from different hosts and different places was done by ooze test in a test tube containing clear sterilized distilled water.

The colonies of all the 57 isolates were well separated, irregular with smooth margins, slimy dull white colonies with a pink to red center on SMSA medium. However some variations in colony characters were observed (Table 2). Based on the morphological studies it was found that all the isolates were gram-negative, rod shaped, noncapsulated and non-spore forming. The isolates were negative for indole and gelatin lignifications, positive for oxidase, levan production, nitrate reduction and did not produce fluorescent pigment on Kings B medium.

\section{Pathogenicity test on different hosts}

All the 57 isolates produced typical wilt symptoms on their respective hosts on being inoculated by root injury technique. Similar methods were followed by Wang and Berk (1997). Artificial inoculation of the pathogen plants expressed symptoms in 3-4 weeks time, while Bird of paradise (BOP), coleus and davana isolates took longer. Thus, on the basis of host range, and the ability to cause wilt in solanaceous and nonsolanaceous plants the 57 isolates were designated as race 1 . On the basis of various morphology and pathogenicity characteristics and on comparison of these characters with the characters reports for $R$. solanacearum from all 57 isolates from different geographical areas, $R$. solanacearum was indentified.

\section{PCR amplification and serological detection}

The genomic DNA was subjected PCR, the PCR amplification resulted in a $\sim 300$ base pair (bp) product for (Y2 \& OLI1) and 292 bp product (Y1 \& Y2) from all 57 isolates of $R$. solanacearum. This is in agreement with the earlier results (Seal et al. 1993) and the tested isolates were grouped into race 1.

Detection of R. solanacearum by Enzyme-Linked Immunosorbent Assay on Nitrocellulose membrane using enriched samples (NCM-ELISA), originally developed to detect latent infection in potato seed tubers, was adopted to authenticate the isolates (Priou et al. 1999). Furthermore, the scFv monoclonal antibody (anti-Ralstonia solanacearum-ALP conjugate) detected $R$. solanacearum (Chandrashekara et al. 2006). The ELISA results obtained were on par to positive control of $R$. solanacearum which was 5-8 times greater than the negative control value, which confirmed the isolates of $R$. solanacearum belong to race 1 , biovars 3 .

\section{DISCUSSION}

The bacterium was isolated on SMSA medium (Elphinstone et al. 1998; Wenneker et al. 1999) where it produced irregular-shaped white colonies with pink centers, resembling those of $R$. solanacearum. All the isolates grown on SMSA medium had similar characteristics with minor variations which are depicted in table. 2 . The colonies were highly fluidal, white coloured with slight pink center and a bluish margin, and round to irregular in shape (Kelman 1954). Brinjal isolates produced copious slime and were highly fluidal. BOP isolate produced miniature colonies with dark red pigmentation in the center of the colony. The isolates did not differ much in cultural characters with the exception of the brinjal isolates.

All the isolates produced typical wilt symptoms in their respective hosts on artificial inoculation by the root injury technique (Wang and Berk 1997). Artificial inoculation of the pathogen plants expressed symptoms in 4-5 weeks time, while BOP isolate took longer. Two ginger isolates could infect all other solanaceous host plants, but failed to infect mulberry and Musa plants. Consequently, on the basis of host range and the ability to cause wilt in solanaceous and non-solanaceous plants, the 57 isolates were designated as race 1 . Similar results were also reported in the past by several workers about prevalence of race in India as race 1 (Khan 1974).

The $R$. solanacearum isolates was classified into different biovars on the basis of their ability to utilize or oxidize three hexose alcohols (mannitol, sorbitol and dulcitol) and three disaccharides (lactose, maltose and cellobiose) (Hayward 1964). Among the 57 isolates, 54 isolates oxidized disaccharides, and hexahydric alcohols tested are presented in table 2. Shekhawat et al. (1978) recorded that strains causing brown rot of potato belonged to race 1 and biovar 3 and 4. In 1992, Shekhawat et al. reported that pathogen isolated from the plains area belonged to race 1 , and that biovar 3, biovar 4 was encountered only among the isolates from eastern parts of India. Race 3 and biovars 2 were obtained only from a few places in the central plains and Deccan plateu. Bhattacharya et al. (2003) reported the prevalence of race 1 and biotype 3 infecting potato, tomato, aurbargine, chilli, jute and banana from West Bengal.

The three isolates from Kerala viz. Kerala Ralstonia solahacearum tomato (KERT-1), Kerala Ralstonia solahacearum ginger (KERG-1 and KERG-2) behaved dif- 
Table 1. Designation of R. solanacearum isolates collected from different agro-climatic zones of Karnataka and other states of India

\begin{tabular}{|c|c|c|c|}
\hline No. & Isolate code & Host & Place \\
\hline 1 & SRP-1 & potato & *Simla (GSC-26) \\
\hline 2 & SRP-2 & potato & ${ }^{*}$ Simla (134) \\
\hline 3 & SRP-3 & potato & *Simla (JGS 3/118) \\
\hline 4 & KRP-4 & potato & Sulebele, Kolar \\
\hline 5 & CRP-6 & potato & Kolar \\
\hline 6 & ChRP-7 & potato & Chikkabalapur \\
\hline 7 & KRP-8 & potato & Chikamaglur \\
\hline 8 & ChRP-6 & potato & Bagepalli, Kolar \\
\hline 9 & BRP-9 & potato & Chikamaglur \\
\hline 10 & HRP-10 & potato & Bangalore \\
\hline 11 & BRP-11 & potato & Kandli, Hassan \\
\hline 12 & KERT-1 & tomato & Kerala \\
\hline 13 & BRT-2 & tomato & Bangalore \\
\hline 14 & KRT-3 & tomato & GKVK, Bangalore \\
\hline 15 & HRT-4 & tomato & Chintamani, Kolar \\
\hline 16 & KRT-5 & tomato & Hassan \\
\hline 17 & BRT-6 & tomato & Sreenivaspura, Kolar \\
\hline 18 & BRT-7 & tomato & Bangalore \\
\hline 19 & KRT-8 & tomato & Hebbal, Bangalore \\
\hline 20 & KRT-9 & tomato & Gouribidnur, Kolar \\
\hline 21 & TRT-10 & tomato & Chintamani, Kolar \\
\hline 22 & BRT-11 & tomato & Hossur, Tamil Nadu \\
\hline 23 & APRT-12 & tomato & Hoskote, Bangalore \\
\hline 24 & KRT-13 & tomato & Anantapur, Andhra Pradesh \\
\hline 25 & BRT-14 & tomato & Malur, Kolar \\
\hline 26 & DRT-15 & tomato & Anekal, Bangalore \\
\hline 27 & KRT-16 & tomato & Davangere \\
\hline 28 & TuRT-17 & tomato & Kaivara, Kolar \\
\hline 29 & MRT-18 & tomato & Tumkur \\
\hline 30 & KRT-19 & tomato & Mysore \\
\hline 31 & ChiRT-20 & tomato & Sreenivaspura \\
\hline 32 & HRT-21 & tomato & Chitradurga \\
\hline 33 & HRT-22 & tomato & Madenur, Hassan \\
\hline 34 & HRT-23 & tomato & Bhuvaneshwar, Orissa \\
\hline 35 & HRT-24 & tomato & Arkalgud, Hassan \\
\hline 36 & HRT-25 & tomato & Kandli, Hassan \\
\hline 37 & TuRT-26 & tomato & Hassan \\
\hline 38 & HRT-27 & tomato & Tumkur \\
\hline 39 & BRT-28 & tomato & Hassan \\
\hline 40 & DhRT-29 & tomato & Kanakpura \\
\hline 41 & SiRT-30 & tomato & Dharwad \\
\hline 42 & BiRT-31 & tomato & Sirsi \\
\hline 43 & KRB-1 & brinjal & Bijapur \\
\hline 44 & HRB-2 & brinjal & Kolar \\
\hline 45 & ARB-3 & brinjal & Kandli, Hassan \\
\hline 46 & ARB-4 & brinjal & Arabhavi \\
\hline 47 & BRCa-1 & capsicum & Arabhavi \\
\hline 48 & CRD-1 & davana & GKVK, Bangalore \\
\hline 49 & BOP-1 & bird of paradise & Chikkabalapur \\
\hline 50 & ORT-1 & tomato & Bangalore \\
\hline 51 & ORT-2 & tomato & Bhuvaneshwar, Orissa \\
\hline 52 & ORB-1 & brinjal & Bhuvaneshwar, Orissa \\
\hline 53 & MRT-1 & tomato & Nasik, Maharastra \\
\hline 54 & MRT-2 & tomato & Nasik, Maharastra \\
\hline 55 & KERG-1 & ginger & Trissur. Kerala \\
\hline 56 & KERG-2 & ginger & Trissur. Kerala \\
\hline 57 & APRC-1 & coleus & Tirupati (AP) \\
\hline
\end{tabular}


Table 2. Morphology of 57 isolates of bacterium on Semi-selective media South Africa (SMSA) media

\begin{tabular}{|l|l|}
\hline \multicolumn{1}{|c|}{ Isolates } & \multicolumn{1}{c|}{ Morphology on SMSA media } \\
\hline $\begin{array}{l}\text { KERT-1, BRT-2, KRT-3, HRT-4, KRT-5, BRT-6, BRT-7, KRT-8, } \\
\text { KRT-9, TRT-10, BRT-11, APRT-12, KRT-13, BRT-14, DRT-15, } \\
\text { KRT-16, TuRT-29, MRT-18, }\end{array}$ & $\begin{array}{l}\text { irregular with smooth margin, slimy dull white colonies with } \\
\text { pink to red center }\end{array}$ \\
\hline $\begin{array}{l}\text { KRT-19, ChiRT-20, HRT-21, ORT-22, HRT-23, HRT-24, HRT- } \\
\text { 25, TuRT-26, HRT-27, BRT-28, DhRT-29, SiRT-30, BiRT-31 }\end{array}$ & moderately fluidal, regularly shaped, convex, red colored colonies \\
\hline $\begin{array}{l}\text { SRP-1, SRP-2, SRP-3, KRP-4, KRT-5, CRP-6, ChRP-7, KRP-8, } \\
\text { ChRP-6, BRP-9, HRP-10, BRP-11, BRCa-1 }\end{array}$ & $\begin{array}{l}\text { moderately fluidal, irregularly shaped, convex, dull white } \\
\text { colonies with pink colored center and bluish margin }\end{array}$ \\
\hline KRB-1, HRB-2, ARB-3, ARB-4 & $\begin{array}{l}\text { dull white colonies with light pink colored center, and the } \\
\text { colonies were highly fluidal and flowing producing copious slime }\end{array}$ \\
\hline ORB-1 & $\begin{array}{l}\text { the colonies were well-separated, fluidal, white colonies with } \\
\text { dark yellow coloring and the colonies were relatively rigid }\end{array}$ \\
\hline BOP-1 & $\begin{array}{l}\text { fluidal, white colonies with dark red colored center and the } \\
\text { colonies were relatively small rigid }\end{array}$ \\
\hline CRD-1, ORT-1, ORT-2, MRT-1, MRT-2, KERG-1, KERG-2 & $\begin{array}{l}\text { highly fluidal, irregularly shaped, convex, dark reddish colonies } \\
\text { with red colored center and whitish margin }\end{array}$ \\
\hline
\end{tabular}

ferently and were unable to utilize dulcitol and lactose. Hence, a new taxonomic group at the subspecies level within the biotype was created and these three isolates have been designated as biovar-3B. Variation in the ability of isolates to utilize sugars such as dulcitol were also reported by Mathew et al. 2002. They designated such strains as biovar 3A. Similarly, Sunaina et al. (1997) found differences among the strains infecting potato in India and the ability of the strains to utilize sugars. One strain could not utilize mannitol and maltose, which was designated as a typical strain.

Sequences of 16Sr DNA and 16Sr RNA genes are often species-specific and are present as multiple copies in microbial genomes, hence they make excellent targets for identification of bacteria at the species level. The corresponding specific rDNA and rRNA sequences have been used as targets for PCR amplification (Woese 1987). The PCR amplification resulted in a $300 \mathrm{bp}$ and $292 \mathrm{bp}$ product from all the 57 isolates of $R$. solanacearum respectively for (Y2 \& OLI1) and (Y1 \& Y2). The amplification conditions allowed the specific detection of $R$. solanacearum isolates. This confirmed that all 57 isolates tested were R. solanacearum. Similar results were obtained by Seal et al. (1993) and isolates tested were grouped in race 1 . The amplification conditions allowed for the specific detection of the isolates of $R$. solanacearum. These primers can be used to diagnose $R$. solanacearum strains. All the isolates produced bright purple coloration at a concentration of $10^{7} \mathrm{cfu} / \mathrm{ml}$ on the nitrocellulose membrane which was compared with the positive control strips provided in the kit (Priou et al. 1999). The scFv monoclonal (antiRalstonia solanacearum-ALP conjugate) antibody also confirmed the detected $R$. solanacearum isolates has race 1 , biovar 3 (Chandrashekara et al. 2006).

\section{CONCLUSIONS}

$R$. solanacearum isolates of Karnataka and other states in India were characterized as race 1 and biovars 3 . A new taxonomic group has been given as biovars $3 \mathrm{~B}$ within the biovar system for the 3 isolates from Kerala, which did not oxidize dulcitol and lactose. Optimization of PCR condi- tions using two sets of universal primers can be used as diagnostic primers for detection and identification of $R$. solanacearum. Serological diagnostic kit International Potato Centre-Enzyme Linked Immunosorbent Assay on Nitrocellulose Membrane (CIP-NCM-ELISA) used in this study confirmed the scope of the kit for detection of the isolates from other host and sub species identification of R. solanacearum and scFv monoclonal (anti-Ralstonia solanacearum-ALP conjugate) to confirm causative organism as $R$. solanacearum race 1 , biovar 3 .

\section{ACKNOWLEDGEMENTS}

The authors are grateful to Indian Council of Agricultural Research (ICAR) for providing the funds for carrying out the research under the National Agricultural Technology Programme - Competitive Grant Program (NATP-CGP) grant. We would like to thank the Indian Institute of Horticulture Research, and the University of Agricultural Science, Bangalore for providing the facilities.

\section{REFERENCES}

Allen C., Prior P., Hayward A.C. 2005. Bacterial Wilt Disease and the Ralstonia solanacearum Species Complex. APS Press, St. Paul, MN, USA, 528 pp.

Anonymous. 1957. Manual of Microbial Methods. Society of American Bacteriologists, McGraw, New York, 315 pp.

Bhattacharya P., Samajpatti N., Bhattacharya P. 2003. Characteristics of Ralstonia (Pseudomonas) solanacearum from Gangetic West Bengal. J. Mycopathol. Res. 41: 15-19.

Buddenhagen I.W., Sequeira L., Kelman A. 1962. Designation of races in Pseudomonas solanacearum. Phytopathology 52, p. 726.

Chandrashekara K.N., Prasannakumar M.K. 2010. New Host Plants for Ralstonia solanacearum from India. Plant Pathology. 59 (6): 11-78. Doi:10.1111/J.1365-3059.2010.02358.X

Chandrashekara K.N., Jagadish K., Krishnamurthy K.B., Rashmi S., Prasanna Kumar M.K., Sathya L., Ibem H.K., Ramachandra Y.L., Akella V. 2006. Single chain antibody fragments transcriptionally fused to ALP specific against Ralstonia 
solanacearum virulent and avirulent strains to detect field samples of infected plants. In: International Bacterial Wilt Symposium. York, England, 17-20 July 2006, 34 pp.

Danks C., Barker I. 2000. On-site detection of plant pathogens using lateral flow devices. Bull. OEPP/EPPO Bull. 30: 421426.

Elphinstone J.G., Stanford H.M., Stead D.E. 1998. Detection of Ralstonia solanacearum in potato tubers, Solanum dulcamara, and associated irrigation water. p. 133-139. In: "Bacterial Wilt Disease: Molecular and Ecological Aspects" (P. Prior, C. Allen, J. Elphinstone, eds.). Springer, 461 pp.

Hayward A.C. 1964. Characteristics of Pseudomonas solanacearum. J. Appl. Bacteriol. 27: 265-271.

Hayward A.C. 1991. Biology and epidemiology of bacterial wilt caused by Pseudomonas solanacearum. Ann. Rev. Phytopathol. 29: 65-87.

Hayward A.C. 2000. Ralstonia solanacearum. Encyclopedia of microbiology. Academic Press, London (GB) 4 (2): 32-42.

He L.Y., Sequiera L., Kelman A. 1983. Characteristics of strains of Pseudomonas solanacearum from China. Plant Dis. 67: 1357-1361.

Kelman A. 1954. The relationship of pathogenicity of Pseudomonas solanacearum to colony appearance in tetrazolium medium. Phytopathology 44: 693-695.

Khan A.N.A. 1974. Studies on Pseudomonas solanacearum (E.F. Smith) causing wilt of brinjal, potato and tomato in Mysore state. Mysore J. Agric. Sci. 8: 478-479.

Priou S., Gutarra L., Fernandez H., Aley P. 1999. Highly sensitive detection of Ralstonia solanacearum in latently infected potato tubers by post enrichment ELISA on nitrocellulose membrane. Bull. EPPO/OEPP Bull. 29: 117-125.

Schaad N.W. 1992. Laboratory Guide for the Identification of Plant Pathogenic Bacteria. 2nd ed. APS Press, St. Paul, MN, USA, 138 pp.
Seal S.E., Jackson L.A., Young J.P.W., Daniels M.J. 1993. Differentiation of $P$. solanacearum, $P$. syzygii, $P$. pickettii and the blood disease bacterium by partial 16S RNA sequencing, construction of oligonucleotide primers for sensitive detection by polymerase chain reaction. J. General Microbiol. 139 (7): 1587-1594.

Shekhawat G.S., Singh R., Kishore V. 1978. Distribution of bacterial wilt and races and biotypes of the pathogen in India. J. Indian Potato Association 5: 155-165.

Smith E.F. 1896. A bacterial disease of the tomato, egg plant and Irish potato (Bacillus solanacearum nov. Sp.), U.S. Dept. Agric. Div. Veg., Physiol. Path. Bull. 12: 1-28.

Sunaina V., Kishore V., Shekhawat G.S., Kumar M. 1997. Control of bacterial wilt of potato in naturally infested soils by bacterial antagonists. J. Plant Dis. Protocol 104: 362-369.

Wang J.F., Berk T. 1997. Sources of resistance to Bacterial Wilt in Capsicum annuum. ACIAR Bacterial Wilt Newsletter 14: 3-4.

Wenneker M., Verdel M. S.W., Van Beuningen A.R., Derks J.H.J., Janse J.D. 1999. Ralstonia (Pseudomonas) solanacearum race 3 (biovar 2) in surface water and natural weed hosts: first report on stinging nettle (Urticadioica). Eur. J. Plant Pathol. 105: 307-315.

Woese C.R. 1987. Bacterial evolution. Microbiol. Rev. 51 (2): 221-271.

Yabuuchi E., Kosako Yano I., Hotta H., Nishiuchi Y. 1995. Transfer of two Burkholderia and an Alcaligenes species to Ralstonia Gen. Nov. Proposal of Ralstonia pickettii (Ralston, Palleroni and Doudoroff 1973) Comb. Nov. Ralstonia solanacearum (Smith 1896) Comb. Nov. and Ralstonia eutropha (Davis 1969) Comb. Nov, Microbiol. Immunol. 39 (11): 897-904. 